\title{
Beggars and Covid 19 Pandemic in Lhokseumawe City, Aceh Province
}

\author{
Cut Sukmawati ${ }^{1, *}$ Bambang Heru Prasatyo ${ }^{2}$
}

\author{
${ }^{1}$ Fakultas Ilmu Sosial dan Ilmu Politik Universitas Malikussaleh \\ ${ }^{2}$ Fakultas Ilmu Sosial dan Ilmu politik Universitas Malikussaleh \\ *Email: cutsukmawati@unimal.ac.id
}

\begin{abstract}
Begging activity has become a familiar sight in Lhokseumawe City. In every corner of this city there are beggars who come, starting from the intersection of traffic lights, restaurants / cafeterias, mosques, even in the campus area there are also beggars. Since the beginning of the year Indonesia has been infected with the Covid 19 pandemic, known as the corona virus. In Lhokseumawe, this case occurred in April 2020. The case that occurred in Lhokseumawe did not make beggars worry about doing their usual activities. It is as if the virus is only a fabrication by certain parties to frighten people to seek income. This paper seeks to analyze the policies of the Lhokseumawe City government in dealing with beggars during the Covid 19 pandemic. Using descriptive analysis methods with a qualitative approach.Data collection techniques using the method of observation, interview and documentation. The data that the researchers obtained were analyzed by several steps, namely data collection, data reduction, data presentation and finally drawing conclusions. The results show that there are no policies specifically made to deal with beggars during the Covid period. The Lhokseumawe City Government only uses policies that have existed before the Covid 19 pandemic, which are aligned with several other policies made during the Covid 19 pandemic.
\end{abstract}

Keywords: policy, beggars and covid 19

\section{INTRODUCTION}

Social welfare problems cannot be avoided in people's lives, especially those in urban areas, namely the problem of street children, homeless people, beggars and buskers. This social problem is an accumulation of various problems that occur, ranging from poverty, low levels of education, lack of work skills, environment, socio-culture, health and so on.

According to Government Regulation or Government Regulation Number 31 of 1980 concerning the Handling of Homelessness and Beggars, it is said that homeless people are people who live in conditions that are not in accordance with the norms of a decent life in the local community, and do not have a place to live and work that remains in certain areas and lives wander in public places. Meanwhile, the definition of Beggar is people who earn income by asking in public in various ways and reasons to expect mercy from others. The PP explains the stages of handling beggars, namely, First, preventive efforts are organized efforts which include counseling, guidance, training, and education. Second, repressive efforts to eliminate vagabonds and beggars, and to prevent it from spreading in the community through authorized institutions. Third, rehabilitative efforts are efforts to support, restore and provide training to homeless people and beggars.

According to Aceh Qanun Number 11 of 2013 concerning Social Welfare in article (1) it is explained that a beggar is someone who earns income by begging in public places or other places through various means and reasons to expect the mercy of others. Aceh is one of the provinces in Indonesia which continues to experience development and renewal. At this time, many things and problems that have been experienced, such as social problems related to street life, Lhokseumawe City, which is a part of Aceh Province, cannot be separated from the phenomenon of these social problems. Massive beggars 
carry out their actions in strategic places in downtown Lhokseumawe. Sometimes their actions are dangerous and can take their health and even their lives. They dare to break through traffic signs (traffic light), and sometimes it can disrupt the flow of transportation, and it is more worrying that in times of the corona virus epidemic 19, beggars do not seem to care about the effect of the virus on them.

Corona viruses are a large family of viruses that cause disease in humans and animals. In humans, it usually causes respiratory infections, from the common cold to serious illnesses such as Middle East Respiratory Syndrome (MERS) and Severe Acute Respiratory Syndrome (SARS). A new type of coronavirus that was discovered in humans since the outbreak occurred in Wuhan China, in December 2019, was then named Severe Acute Respiratory Syndrome Coronavirus 2 (SARS-COV2), and causes Coronavirus Disease-2019 (COVID-19). (http://infemerging.kemkes.go.id/)

Table 1

Number of beggars caught during raids by the Social Service

\begin{tabular}{|c|c|c|c|c|c|}
\hline No & Years & Children & $\begin{array}{c}\text { Local } \\
\text { Residents }\end{array}$ & Arrivals & Total \\
\hline 1 & 2019 & $\begin{array}{c}11 \\
\text { people }\end{array}$ & 6 people & $\begin{array}{c}15 \\
\text { people }\end{array}$ & $\begin{array}{c}32 \\
\text { people }\end{array}$ \\
\hline 2 & 2018 & - & 5 people & $\begin{array}{c}20 \\
\text { people }\end{array}$ & $\begin{array}{c}25 \\
\text { people }\end{array}$ \\
\hline
\end{tabular}

Sourcer: Lhokseumawe City Social Service, 2020

The background of Lhokseumawe City as a city that adheres to Islamic law, is used by beggars where the generosity and help of people in giving alms is a great opportunity for them to beg. From the results of observations, the researchers found that the beggar was the same person every day. During the observation in the field, the researcher found 33 beggars scattered at traffic lights, intersections and restaurants. Here the researcher argues that the problem of beggars is not a trivial problem, because the number of beggars in Lhokseumawe shows that begging is something that provides a great opportunity to earn income. The Municipal Government of Lhokseumawe at certain times conducts raids on beggars, but beggars are never deterred from begging. The most common reasons for beggars are physical limitations and lack of skills to work and cause them to not be able to support their families. Begging is a last resort for their economic problems.In accordance with this phenomenon, the author wants to know and describe about "How to handling of beggars by the Lhokseumawe City Government?"

\section{RESEARCH METHOD}

This paper departs from research conducted in Lhokseumawe City. The research approach used is a type of research with descriptive qualitative methods. The technique of taking infoman with purposive technique. Meanwhile, the informants of the beggar writer used the random sampling technique.In taking data sources, the writer divides them into two types of sources, namely: (1) Primary data sources, these data sources come from field observations and in-depth interviews, (2) Secondary data sources, This is obtained from books or journals that are used as references in the writing of this research which can support this research information.Data analysis carried out is guided by Miles and Huberman (1992), namely by: (1) Data collection, in collecting data the author obtains information and data through documentation, observation and interviews, which have been carried out on research informants both from Social Service officials, academics and beggars by noting important things that need to be included; (2) Data reduction, at this stage the writer selects from the data that has been previously collected. The author focuses the existing data to be more specific and in-depth, the author has also sorted out which ones need to be included and which ones don't; (3) Presentation of data, the author presents information and data that has been previously collected to be more interesting to be seen and read by others.

\section{GENERAL DESCRIPTION OF BEGGARS IN LHOKSEUMAWE CITY}

The phenomenon of beggars in the city of Lhokseumawe has become commonplace for the people of Lhokseumawe. Begging is not an act that violates the law, but if you look at the massive development of beggars, of course the question arises, why are there more beggars, especially during the Covid 19 pandemic? Is there no government action? Many beggars are seen not using health protocols such as masks, where they can become intermediaries between people who have been exposed and people who have not been exposed to COVID 19.

There are several reasons put forward by academics, as stated by the Lecturer at the University of Malikussaleh, Rahmad Syahputra Rangkuti, S.Sos.,M.Sos as the Head of the Sociology Study Program, who said that:

"Sociologically, urban, homeless and beggars emerge from the aspect of not being absorbed by all people who are urbanized into the city so that there are two jobs that emerge, their formal sector which is able to get in there with a fixed salary and one is the informal sector. who enter there are what is meant by vagabonds and beggars. And it becomes one of the urban problems ". 
Agree with this, Teuku Kemal Pasya, S.Ag.,M.Hum as Lecturer in Anthropology, said:

\footnotetext{
"In general, beggars are the impact of poverty or unreachable welfare, begging is not only a problem of poverty but also a cultural problem".
}

However, behind it all, the phenomenon of the increasing number of beggars in the city of Lhoksemawe during the COVID 19 pandemic is an interesting thing to research, and the author explains some of the discussions about beggars below.

\subsection{Beggar's Origin}

Handling beggars is one of the duties and authorities of the Social Service. Handling beggars is not something that can be considered easy to solve, it requires cooperation not only between the Social Service and Satpol PP but also requires collaboration with the city government, non-governmental organizations and the community to solve this problem. Based on the researchers' interviews with sources, it was found that the majority of beggars did not come from Lhokseumawe City. As stated by R.R Yustirostina, SE as the Head of the Section for social rehabilitation, disability and social disabilities, that:

"The beggars in Lhokseumawe are mostly or more dominant as long as they are not residents of Lhokseumawe City, we ourselves as the Social Service know this during the raid, and when it is recorded, they are mostly from outside Lhokseumawe City".

In the same vein, the researchers found recognition from the beggars themselves. Namely Lamuli and Darmiati as follows:

"I am not a Lhokseumawe person, my village is from Panton Labu, I go here with my motorbike, by my self. My son is still young and he is a student, so I go alone".

"Grandma now lives in Nisam, so if i come here, my grandchildren will take me and also pick me up again".

In carrying out their activities, beggars have their own motives or ways. They use different motives to make people feel sorry and sorry for them so that they get alms. In how many cases there were beggars who were pushy, they would not leave without money. During the study, researchers divided into two groups, namely first, organized beggars and second, unorganized beggars.Organized begging is usually carried out by children, and they have a target income for one begging. From Akhyar's narrative, it is concluded that he started begging at night after maghrib, then at one time begging he had a target of 70 thousand. And if he doesn't get it he doesn't have to go home yet. At 12 o'clock at night he finished begging and if he had enough money he went home in a rickshaw, if not he walked home. Unorganized Beggars is a beggar who is usually found on red lights and in cafes or restaurants. Usually they do their own unstructured activities only alone or together.

\section{HANDLING OF BEGGARS 4.1 Handling Of Beggars Before The Covid 19 Pandemic}

In handling beggars in the city of Lhokseumawe, the government itself through the Social Service has made efforts to deal with the increase in beggars before the COVID 19 pandemic. The handling of beggars itself is divided into 3 stages in accordance with Government Regulation No. Rehabilitative. At the preventive stage, the Social Service has made an appeal board to give donations and charity at the institutions or institutions that have been designated, this board is installed in Riyadh Park and a red light in front of the Suzuya Department store. In addition, social assistance in the form of Unfit for Living (RTLH) assistance, the Family of Hope Program (PRH) and assistance to poor and physically disabled people (modified tricycle motorbikes, goods engine pedicab) and Productive Economic Business assistance (UEP).

At the repressive stage, the Social Service has taken control measures in the form of raids and taken to the Satpol PP office and then given instructions to beggars not to beg, they are recorded as their names, origins or places of residence then their reasons for begging and they are asked to sign a statement not to beg again. after that, they were given food and then escorted back to their respective homes if residents of Lhokseumawe and if they came from outside the city they would be given a fare to go home. But so far there has been no deterrent effect. The Office of Social Affairs could not arrest them because if they were arrested they did not know where to place them because there were no open houses.

At the rehabilitative stage, the Social Service does not have shelter or shelter for homeless people and beggars. Halfway houses are needed to accommodate homeless people and beggars and provide guidance to them in the form of skills training so that they can restore their social function. 
This is as said by Susi Hermiza, SH as the Head of the Social Security Rehabilitation and Protection Division, he said:

"The Social Service gave directions not to beg again, then we made a statement so that we didn't repeat it again, but I saw that there was no effect of the traps, I don't know why, if we catch them we don't know where they will be placed because we don't have a shelter, and because of lack of funding, I just give them guidance for a while ".

\subsection{Handling Beggars During the COVID 19 Pandemic.}

The phenomenon of beggars is very interesting to study, what causes the increase in beggars and how the government responds to this problem, especially during the COVID 19 pandemic. Masks have carried out socialization and curb health protocol violators.

In accordance with the disclosure of dr. Said AlamZulfikar stated that in Lhokseumawe City, the cumulative number of patients exposed to COVID-19 continued to increase to 37 people. From these data we know that the increase in exposed people is quite large. The more who are exposed, the more prone people are to be exposed to this corona virus. During the research, many people did not use masks, especially beggars. Here the role of beggars in transmitting COVID 19 is very influential as an intermediary between people who have been exposed and people who have not been exposed. Where beggars ask for donations and come into contact with strangers and as a result of not wearing masks, the more likely they are to be exposed.

The existence of cases of patients exposed to Covid 19 does not make beggars worry and take care of themselves, it is even more justification for their actions. They argue that the growing pandemic has made it even more difficult for them. But on the other hand they are not always guilty, because they are only trying to make a living to meet their daily needs. So that they are forced to keep begging during this pandemic, and this should be of particular concern for the Social Service to take appropriate and efficient policies.

During this pandemic the city government of Lhokseumawe did not take action in dealing with beggars. The Social Service cannot carry out raids against beggars due to the COVID pandemic.

They were supposed to carry out raids in April, but eventually it had to be canceled. As stated by Susi
Hermiza, SH as Head of Social Security Rehabilitation and Protection:

"For the time of this pandemic, we did not have any activities, either raids or other activities related to beggars. In April, we should have held a sweep, but because of COVID 19 we canceled it, because it was not justified to make a crowd".

\section{CONCLUSION}

From the results of the analysis, several conclusions were obtained, namely:

1. In carrying out their activities, beggars have their own motives or ways. They use different motives to make people feel sorry and sorry for them so that they get alms. In how many cases there were beggars who were pushy, they would not leave without money. There are two categories of beggars; first, organized beggars and second, unorganized beggars.

2. Lhokseumawe in the period before Covid 19 was divided into three stages, including: (1) Preventive, namely social assistance in the form of Unworthy Housing (RTLH) assistance, the Family Hope Program (PRH) and providing assistance to poor and physically disabled residents (motorbikes modified tricycle, goods engine pedicab) as well as Productive Economy Business assistance (UEP). The Social Service has also put up a sign saying not to beg and give alms to beggars on the side of the road but to make donations to established institutions; (2) Repressive is an effort to reduce or eliminate homeless people and beggars, by carrying out raids and then temporary accommodation and signing a statement letter not to beg again and then returning the beggars; (3) Rehabilitation is the government's effort in handling beggars by means of efforts to accommodate, select, support and provide assistance in this effort so that their social function can be restored. At this stage it cannot be implemented, becauseno shelter.

3. During the Covid 19 pandemic, the Lhokseumawe City government could not handle massive beggars. Only briefed through billboards and bulletin boards to implement health protocols. The appeal is aimed at the general public, not specifically for beggars. Even though beggars are very vulnerable to being exposed to Covid 19 due to interactions with many people. 


\section{ACKNOWLEDGMENTS}

This research was conducted in Lhokseumawe City with the full support of the Head of the Faculty of Social and Political Sciences, Malikussaleh University. The Municipal Government of Lhokseumawe, particularly the Social Service, has provided sufficient information for this study. Especially to beggars who want to share stories of joy and sorrow. Students who have contributed, as well as colleagues at the Faculty of Social and Political Sciences, especially Teuku Kemal Fahsya and Rakhmadsyah Rangkuti who have shared their thoughts on beggars and social dynamics. To all, thank you profusely.

\section{REFERENCES}

\section{Book}

[1] Anggara, Sahya. (2014). Kebijakan publik, Bandung: Pustaka Setia

[2] Arifuddin, Alfan, (2017), psikologi pengemis,Malang: Gunung samudera [3] C. Baier, J-P. Katoen, Principles of Model Checking, MIT Press, 2008.

[4] Bungin, M. Burhan, (2007), Penelitian Kualitatif, Cetakan keempat, Jakarta: Kencana Prenada Media Group.

[5] Dunn, William N, (2003), Pengantar Analisis Kebijakan Publik, Edisi kedua, Yogyakarta: Gadjah Mada University Press

[6] Fermana, Surya, (2009), Kebijakan Publik, Yogyakarta: Ar-Ruzz Media.

[7] Thoha, Miftah (2008), Ilmu Administrasi Publik Kontemporer, Edisi Pertama, Jakarta: Kencana Prenadamedia Group

[8] Parsons, Wayne, (2006), Public Policy: Pengantar Teori Dan Praktek Analisis Kebijakan, Cetakan Kedua, Jakarta: Kencana Prenada Media Grup

[9] Suharto, Edi, (2005), Analisis Kebijakan Publik, Bandung: Alfabeta

[10] Suharto, Edi, (2008), Kebijakan Sosial Sebagai Kebijakan Publik, Bandung: Alfabeta

[11] Suharto, Edi, (2009), Kemiskinan dan Perlindungan Sosial di Indonesia, Bandung: Alfabeta.

[12] Taufiqurakhman,(2014), Kebijakan Publik, Cetakan pertama, Jakarta: Universitas Moestopo Beragama Pers

\section{Website/internet}

https://www.google.com/amp/s/aceh.tribunnews.com/am p/2019/07/30/pengemis-di-lhokseumawe-banyakwarga-luar accessed on 10 September 2020

https://www.google.com/amp/s/aceh.tribunnews.com/am p/2019/09/19/miris-tak-bawa-uang-usai-mengemisbocahs-lhokseumawe-ini-diduga-dipukul-hinggadirantai-orangtuanya accessed on 10 September 2020

https://stoppneumonia.id/informasi-tentang-virus-coronanovel-coronavirus/ accessed on 25 September 2020

https://aceh.antaranews.com/berita/159810/positif-covid19di-lhokseumawe-meningkat-gtpp-terusmaksimalkan-upaya-penanganan accessed on 25 September 2020

https://aceh.tribunnews.com/2020/09/15/tak-pakaimasker-di-lhokseumawe-dikenakan-sanksimembersihkan-rumput-di-taman-dan-hafal-ayatquran accessed on 15 September 2020

https://aceh.tribunnews.com/2020/09/15/pemerintahaceh-tak-punya-roadmap-penanganan-covidparahnya-lagi-merasa-pintar-sendiri accessed on 15 September 2020 